\title{
STABILIZATION OF MINORITY CARRIER LIFETIME IN PERC STRUCTURED SILICON SOLAR CELL
}

\author{
Veysel Ünsür ${ }^{1^{*}}$
}

\begin{abstract}
This paper reports on the regeneration of the minority carrier lifetime in passivated emitter and rear cell (PERC) structured silicon solar cells. It is observed that minority carrier lifetime in the cells can degrade, recover and then stabilize with illumination level of $\sim 1$ sun $\left(1000 \mathrm{~W} / \mathrm{m}^{2}\right)$ at $80^{\circ} \mathrm{C}$. The exposure to $\sim 1$ sun illumination at $80^{\circ} \mathrm{C}$ enables the release of $\mathrm{H}$ from B-H bonds at $\sim 1.3 \mathrm{eV}$ energy to supplement the interstitial $\mathrm{H}$ in $\mathrm{Si}$ to passivate the B-O defects responsible for the minority carrier lifetime instability. Passivation of these B-O defects is therefore, dependent on temperature and time, hydrogenation and high carrier injection level. It was interesting to note that sequential process or single regeneration step led to same conclusion that minority carrier lifetime in a p-type PERC cell first degrades, due to B-O complexes, recovers and then stabilize with time. There is therefore, no need to degrade the cells in a separate step in order for regeneration to occur, because regeneration encompasses the three states: degradation, recovery and stabilization.
\end{abstract}

Keywords: Light induced degradation (LID), Regeneration, Lifetime, PERC, hydrogenation, solar cells

\section{INTRODUCTION}

Boron-doped Czochralski $(\mathrm{Cz})$ silicon $(\mathrm{Si})$ wafers have been known to lose absolute efficiency up to $1-2 \%$ by light induced degradation (LID) [1] due to the formation of boron-oxygen (B-O) defects. Recombination-active B-O defects are activated under illumination or by applying a forward bias voltage in the dark because of high oxygen and boron concentration in the $\mathrm{Cz}$ silicon bulk material. While the exact form of the defect is still debatable, the recombination behavior of B-O defects is typically described by Shockley-Read-Hall (SRH) trap assisted recombination. These recombination centers are accountable for limiting the performance of solar cells by degrading the minority carrier lifetime. The recombination activity of B-O defects can be reduced to negligible values by; (i) reducing $\mathrm{O}$ concentration in $\mathrm{Cz}-\mathrm{Si}$ wafer using magnetic fields during crystal growth, which will increase the cost of wafer (ii) using dopants other than B such as Gallium (Ga) or Indium (In), (iii) replacing p-type wafers with n-type causing to more complex processing steps (iv) reducing B dopants in the wafer leading to high resistance wafers. Since all replacement measures mentioned implicate new problems or cause a tradeoff in efficiency, many studies have been done to resolve the issue of LID. Researchers have first suggested [2,3] that the defects can be deactivated by annealing the degraded $\mathrm{Cz}$-Si solar cells at low temperatures $\left(\sim 200^{\circ} \mathrm{C}\right)$ or by using rapid thermal processing $[3,4]$ at higher temperatures $\left(\sim 750^{\circ} \mathrm{C}\right)$. However, it was shown [6] that the cells that are treated with annealing process (with high or low temperature) are degraded again under illumination that proves annealing process is not permanent. Therefore, an approach that is capable of removing B-O defects permanently was first reported by Herguth [7] called three-state regeneration model (see Figure 1).

Regeneration process occurs via illumination at elevated temperatures that provides thermal energy and carrier injection simultaneously. Regeneration differs from annealing process by promoting the carrier injection while at elevated temperatures $\left(70^{\circ} \mathrm{C}-200^{\circ} \mathrm{C}\right)$. Studies $[8,9,15-17]$ have also shown that during regeneration, the presence of hydrogen $(\mathrm{H})$ source, mostly anti-reflection coating (ARC) layer of SiNx:H,is necessary to passivate B-O defects. Therefore, the regeneration kinetic is expected to change by (i) minority carrier injection level $(\Delta \mathrm{n})$, (ii) temperature (T), and (iii) presence of hydrogen. It is investigated in this paper how passivated emitter and rear cell (PERC) solar cells respond to the LID and regeneration. Since the LID manifests in silicon bulk, it is the minority carrier lifetime that it will impact first.

This paper was recommended for publication in revised form by Regional Editor Mohammad Rahimi-Gorji 


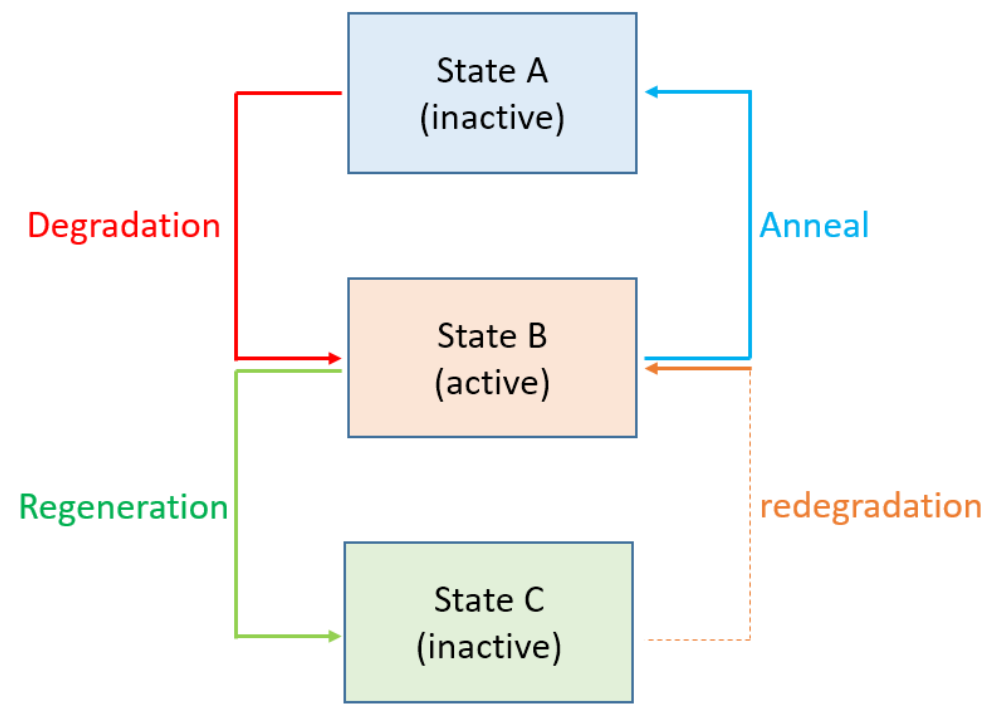

Figure 1. Original 3-state modeled proposed by [7]

Therefore, in this work, the effective minority carrier lifetime $(\tau)$ of the $\mathrm{Cz}$ cSi PERC solar cell was closely monitored; after (i) contact co-firing, (ii) exposure to injection level of 0.1 -sun at $40^{\circ} \mathrm{C}$, (iii) recovery - exposure to $\sim 1$ sun at $80^{\circ} \mathrm{C}$, and (iv) regeneration. Conventional there-state model claims that there is a state $\mathrm{C}$ where $\mathrm{B}-\mathrm{O}$ defects are inactive and may not be irreversible by regeneration process. However, based on this study, a new 3-state model is proposed where the transitions among states are different than that of first proposed model. In this model, separate degradation process is not required to reach state $\mathrm{C}$ from state $\mathrm{A}$. And regeneration occurs directly between state $\mathrm{A}$ and state $\mathrm{C}$. Based on lifetime stability, the three-state model is modified to rationalize the observation in this paper.

\section{EXPERIMENTAL DETAILS}

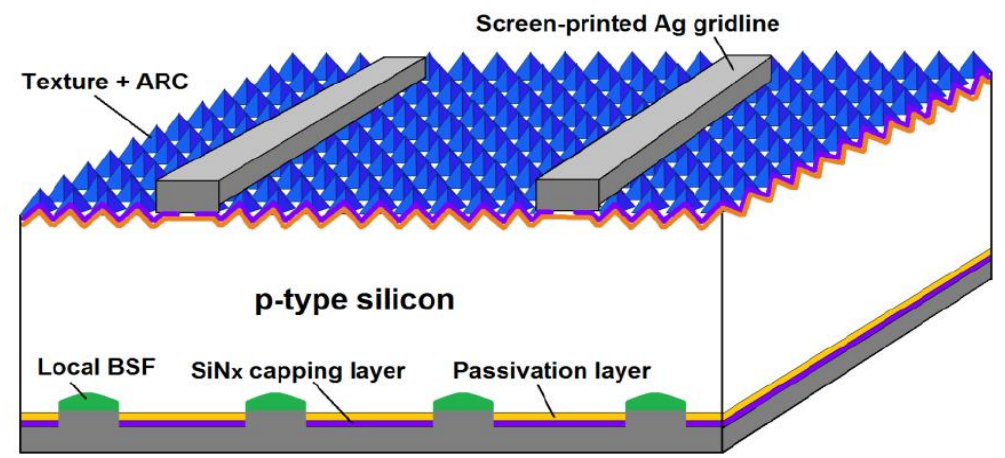

Figure 2. Schematic diagram of passivated emitter and rear cell (PERC) structured solar cell.

Large-area $\left(239 \mathrm{~cm}^{2}\right)$ commercial boron doped p-type $2.5 \Omega \cdot \mathrm{cm} \mathrm{Cz-Si} \mathrm{wafers} \mathrm{were} \mathrm{used.} \mathrm{A} \mathrm{3-busbar} \mathrm{PERC}$ structure was utilized in this experiment. As seen in Figure 2, p-type Si forms a p-n junction with n-type Si. N-type part forms the emitter which absorbs the incident photon and create an electron-hole pair when the cell is illuminated. To be able to capture more photons, the front surface is textured which forms a rough surface so that the incident light could have second chance should it be reflected. It is also coated with anti-reflection layer that acts as a passivation layer of dangling bonds of $\mathrm{Si}$ as well. On the back side there is another passivation layer (capping layer) to enhance the back surface reflection, which contributes to minority carrier collection from the bulk. Since the capping layer is a dielectric, laser processing is applied to make openings on the back side so that aluminum back electrode can make a contact with underlying Si. The cell processing includes: (i) random texturing of both front and 
back sides, (ii) $\mathrm{POCl}_{3}$ diffusion, (iii) edge isolation plus backside planarization and phosphorus removal, (iv) $\mathrm{Al}_{2} \mathrm{O}_{4} / \mathrm{SiN}_{\mathrm{X}}$ deposition on the backside, (v) $\mathrm{SiN}_{\mathrm{X}}$ on the front side, (vi) backside laser printing for $\mathrm{Al}$ holes, (vii) $\mathrm{Al}$ printing on the backside and dry, (viii) Ag/Al back pad and dry, (ix) front side Ag screen printing and dry and finally (x) contact co-firing in IR belt furnace with $\sim 790^{\circ} \mathrm{C}$ peak temperature at 230 inches per minute belt speed which a typical peak temperature profile is shown in Figure 3.

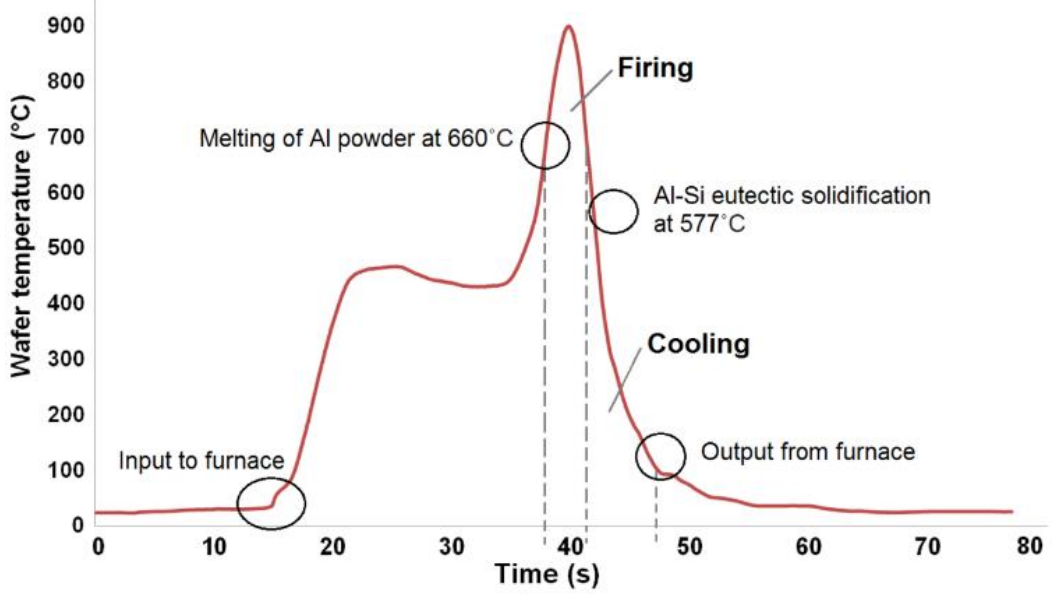

Figure 3. A typical firing profile for conveyor-belt furnace

Three sets of solar cells were used in this experiment. The first set of cells was exposed to light generated with a halogen lamp of $\sim 0.1$-sun intensity at a temperature of $40 \pm 2^{\circ} \mathrm{C}$ (measured cell temperature) for a total time of 120 hours. This ensured the cells were fully degraded. Then the same cells were subjected to 1-sun light intensity at $\sim 80^{\circ} \mathrm{C}$ temperature for 120 hours. Finally, the same set of cells was put under 0.1 sun light intensity to ascertain permanent recovery or stability. The second set was subjected to same setup by first, subjecting to $\sim 1$-sun intensity at $\sim 80^{\circ} \mathrm{C}$ temperature; and then to 0.1 -sun at $40^{\circ} \mathrm{C}$ temperature. The third set was only exposed to 1 -sun at $80^{\circ} \mathrm{C}$ for a total of 240 hours. The current-voltage (I-V) measurements were carried out to monitor the effect of LID on short circuit current ( $\left.\mathrm{I}_{\mathrm{SC}}\right)$, open circuit voltage $\left(\mathrm{V}_{\mathrm{OC}}\right)$, ideality factor (n) and fill factor (FF)). Also, the effective minority carrier lifetime was measured for each cell after $30 \mathrm{~min}, 1 \mathrm{~h}, 3 \mathrm{hrs} 24 \mathrm{hrs}, 48 \mathrm{hrs}, 72 \mathrm{hrs}$, 96hrs, and $120 \mathrm{hrs}$. It is important to point out that lifetime measurements for every step is an average of three randomly picked-points on the same cell.

\section{RESULTS AND DISCUSSION}

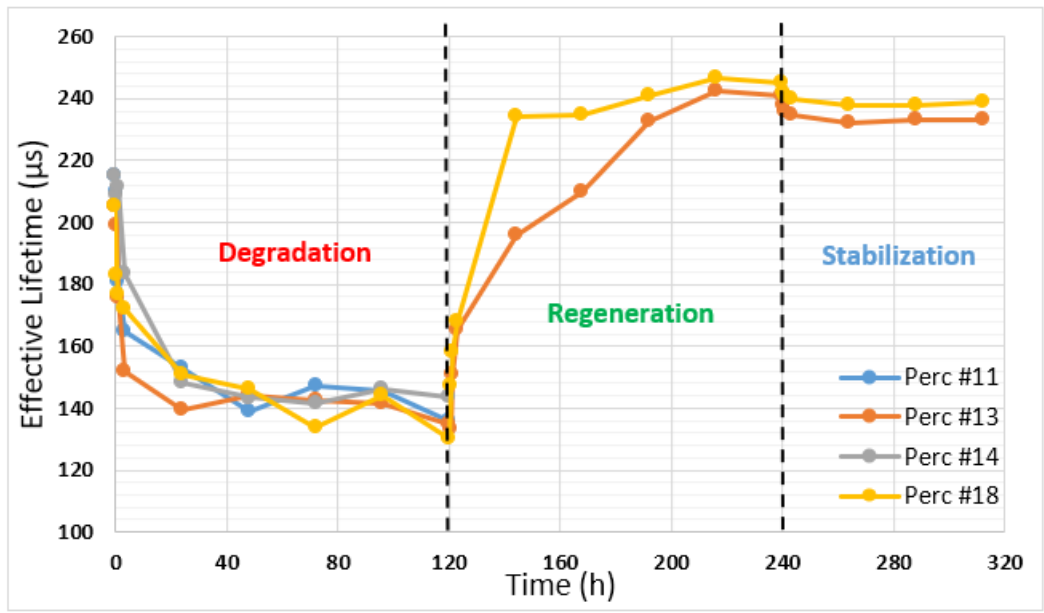

Figure 4. Cells first degraded under illumination at $35^{\circ} \mathrm{C} \sim 40^{\circ} \mathrm{C}$ but subsequently performed regeneration $\left(70^{\circ} \mathrm{C} \sim 100^{\circ} \mathrm{C}\right)$ and stabilization $\left(35^{\circ} \mathrm{C} \sim 40^{\circ} \mathrm{C}\right)$ 
Figure 4 shows the trend of LID behavior of PERC samples for different phases - degradation, regeneration and stabilization. First, the cells when exposed to light intensity of $\sim 0.1$-sun for total time of $120 \mathrm{hrs}$ at $<40^{\circ} \mathrm{C}$, went through "degradation". During degradation, the oxygen in the Si crystal form B-O complexes with boron dopant atoms. Thus, the effective lifetime of $\sim 210 \mu$ s initial value is degraded to around $140 \mu$ s after 120 hours. Notice that, after $\sim 30$ hours, B-O defect formation is complete and hence a minimal change in the effective lifetime.

Secondly, the same set of cells were exposed to 1 -sun light intensity at $80^{\circ} \mathrm{C}$ temperature for "regeneration". Throughout the regeneration, the $H$ in the Si bulk is mobilized, that will be explained later, because of higher temperature and passivate the B-O defects. In addition, the higher injection level due to high intensity light (1-sun) during regeneration may help with exciting the defects from ground state to excited state, which increases the probability of passivation of B-O defects. Also, the mobility of $H$ in the crystal structure with higher injection level is increased and hence the passivation. Therefore, the minority carrier lifetime of $\sim 140 \mu$ s is increased to $\sim 240 \mu s$.

Finally, the cells were exposed to 0.1 sun light intensity to affirm permanent recovery or stabilization. As seen in Figure 4, effective minority carrier lifetimes are higher than the initial values after regeneration and it is stable.

The second set of cells skipped the degradation and is directly put under regeneration process $\left(1\right.$-sun, $\left.80^{\circ} \mathrm{C}\right)$. As Figure 5 suggests, a fast degradation phase occurs in the first hour and regeneration starts subsequently. These results show that there is no need for separate degradation step as suggested in other studies before regeneration. In fact, minority carrier lifetime of $\sim 150 \mu$ s increases to $\sim 180 \mu$ s after regeneration. Figure 5 . also shows that the same cells have recovered and stable when exposed to 0.1 sun light intensity at $40^{\circ} \mathrm{C}$ afterwards.

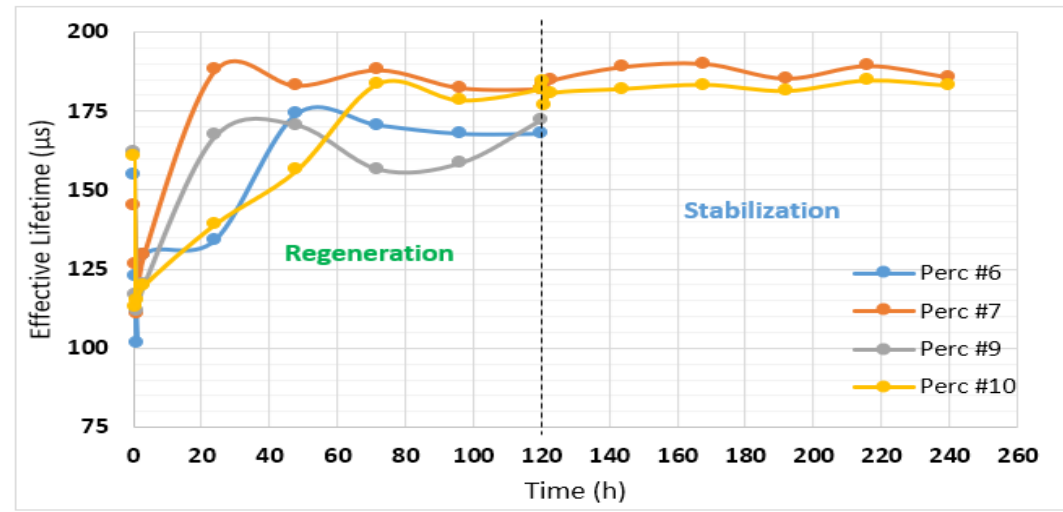

Figure 5. Cells first regenerated under illumination at $70^{\circ} \mathrm{C} \sim 100^{\circ} \mathrm{C}$ and stabilization $\left(35^{\circ} \mathrm{C} \sim 40^{\circ} \mathrm{C}\right)$

Figure 6 shows the results of the third set of cells that went through only regeneration step - 1-sun at $80^{\circ} \mathrm{C}$ for $\sim 250$ hours. In the first hour, the degradation takes place and immediately after degradation the effective lifetime starts to increase (recovery) and then stabilizes. Thus as Figure 6 portrays, regeneration process encompasses degradation, recovery and stabilization of the cell.

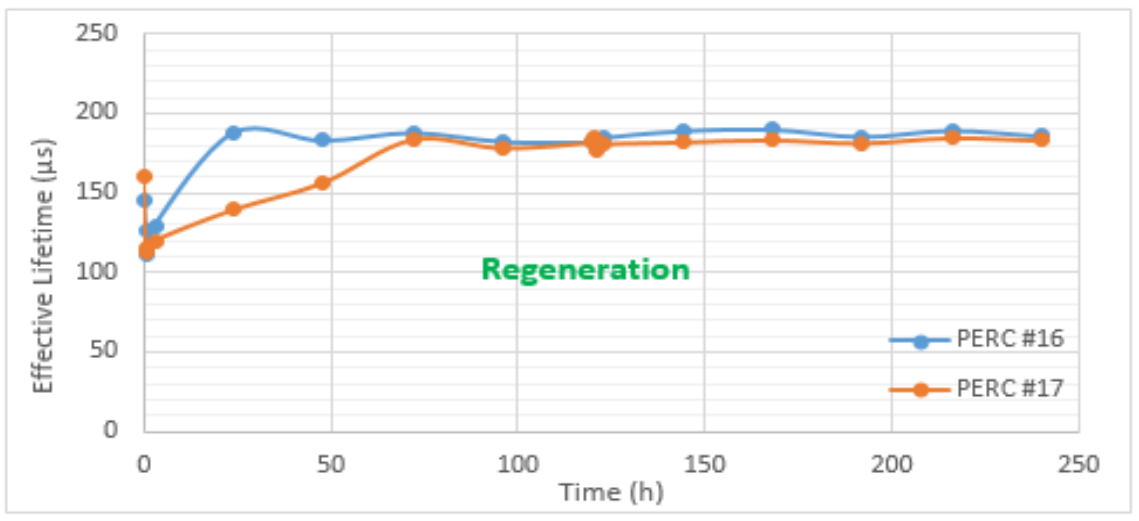

Figure 6. Cells regenerated under illumination at $80^{\circ} \mathrm{C}$ 
Internal quantum efficiency (IQE) of a randomly selected sample from the third set was measured before and after regeneration as shown in Figure 7. As seen, the two curves are perfectly matched, which implies that the B$O$ defects caused by LID are annihilated after regeneration.

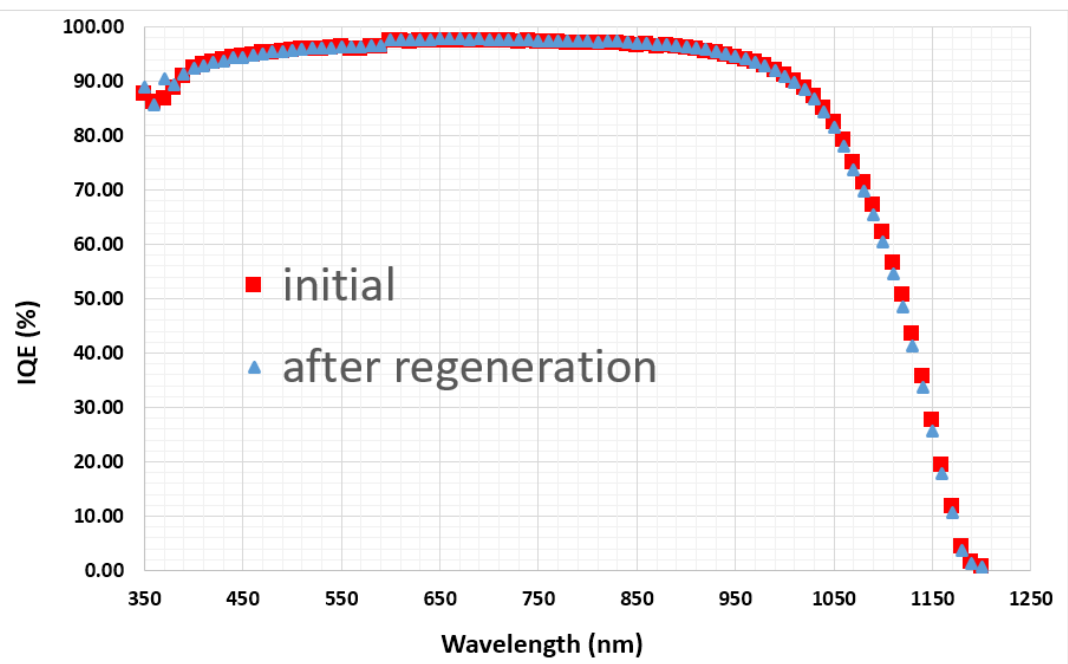

Figure 7. Internal quantum efficieny comparion among the initial, after LID and after regeneration processes

Table I shows the electrical output parameters of one sample from all three sets along with ideality factor. As observed from the table, the efficieny of first set of cells stayed under initial values, whereas the second and third set exceeded their starting efficiencies. It is also well known that ideality factor ( $\mathrm{n}$-factor) is an indicator of recombination centers in the same way of B-O defects. $\mathrm{n}$-factor of the cells are also shown in the Table I. As one can see, it didn't return to initial values for the first set, which somehow implicates that there might be some nonpassivated defects left behind.

Table 1.The electrical outputs of perc silicon solar cells after LID,regeneration and stabilization

\begin{tabular}{lccccc}
\hline \hline Cell ID & n-factor & $\begin{array}{c}\text { V } \\
(\mathrm{mV})\end{array}$ & $\begin{array}{c}\mathrm{J}_{\mathrm{SC}} \\
\left(\mathrm{mA} / \mathrm{cm}^{2}\right)\end{array}$ & $\begin{array}{c}\mathrm{FF} \\
(\%)\end{array}$ & $\begin{array}{c}\text { Efficiency } \\
(\%)\end{array}$ \\
\hline \#13-initial & $\mathbf{1 . 0 8}$ & $\mathbf{6 4 9}$ & $\mathbf{3 9 . 7 8}$ & $\mathbf{8 0 . 9}$ & $\mathbf{2 0 . 9 2}$ \\
\#13-degradation 120h & 1.18 & 639 & 39.38 & 79.4 & 19.99 \\
\#13-regenaration & $\mathbf{1 . 1 0}$ & $\mathbf{6 5 4}$ & $\mathbf{3 9 . 7 1}$ & $\mathbf{7 9 . 5}$ & $\mathbf{2 0 . 6 7}$ \\
\#13-stabilization & 1.11 & 655 & 39.68 & 80.3 & 20.87 \\
\#10-initial & $\mathbf{1 . 1 0}$ & $\mathbf{6 5 0}$ & $\mathbf{3 9 . 9 4}$ & $\mathbf{8 0 . 1}$ & $\mathbf{2 0 . 8 1}$ \\
\#10-regeneration 120h & 1.06 & 652 & 39.95 & 80.4 & 20.89 \\
\#10-stabilization & $\mathbf{1 . 0 6}$ & $\mathbf{6 5 2}$ & $\mathbf{3 9 . 9 4}$ & $\mathbf{8 0 . 0 5}$ & $\mathbf{2 0 . 8 4}$ \\
\#16-initial & $\mathbf{1 . 0 7}$ & $\mathbf{6 5 1}$ & $\mathbf{3 9 . 9 6}$ & $\mathbf{8 0 . 3}$ & $\mathbf{2 0 . 8 6}$ \\
\#16-regeneration 120h & 1.05 & 652 & 39.94 & 80.6 & 21.01 \\
\hline \hline
\end{tabular}

\section{The Kinetic of Regeneration Process}

The three-state model proposed by Herguth [7] suggests that inactive B-O defects (state A) get activated to state B by illumination with low intensity at low temperature. State B is a reversible state by annealing (with hot plate, RTP, laser etc.) to state $\mathrm{A}$. Thus, there-state model claims that there is a state $\mathrm{C}$ where $\mathrm{B}-\mathrm{O}$ defects are inactive and may not be irreversible by regeneration process (see Figure 1.). However, based on Figure 6, a 3-state model is proposed as shown in Figure 8, where the transitions among states are different than Herguth's [7]. In this model, 
separate degradation process is not required to reach state $\mathrm{C}$ from state $\mathrm{A}$. And regeneration occurs directly between state $\mathrm{A}$ and state $\mathrm{C}$.

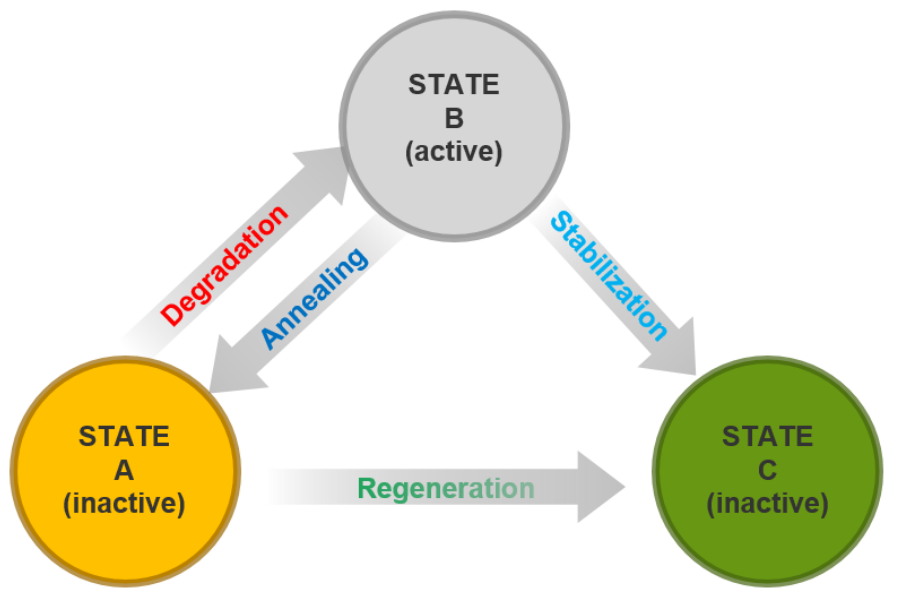

Figure 8. Modified three-state model of LID

There are three major factors that drive the regeneration process; temperature, hydrogen in the Si bulk, and minority carrier injection level during regeneration. In addition, the cell structure may influence regeneration kinetic parameters. For example, PERC cells have higher injection level under same light intensity than Al-BSF in addition to higher concentration of $H$ because of ARC layer on both sides. However, it should be noted that the passivation of the defect relies on the $H$ retention rather than the total amount of $H$ in the ARC films.

\section{Temperature Effect}

Elevated temperature is needed for regeneration process in order for B-O complex to be passivated by $H$. The activation energy $\left(E_{A}\right)$ for passivation is determined according to Arrhenius equation (Equation. 1).

$$
r=A \cdot \exp \left(\frac{E_{A}}{k_{B} T}\right)
$$

where $r$ is the rate constant, $A$ is frequency constant, $E_{A}$ is activation energy, $k_{B}$ is Boltzman constant and $T$ is temperature.

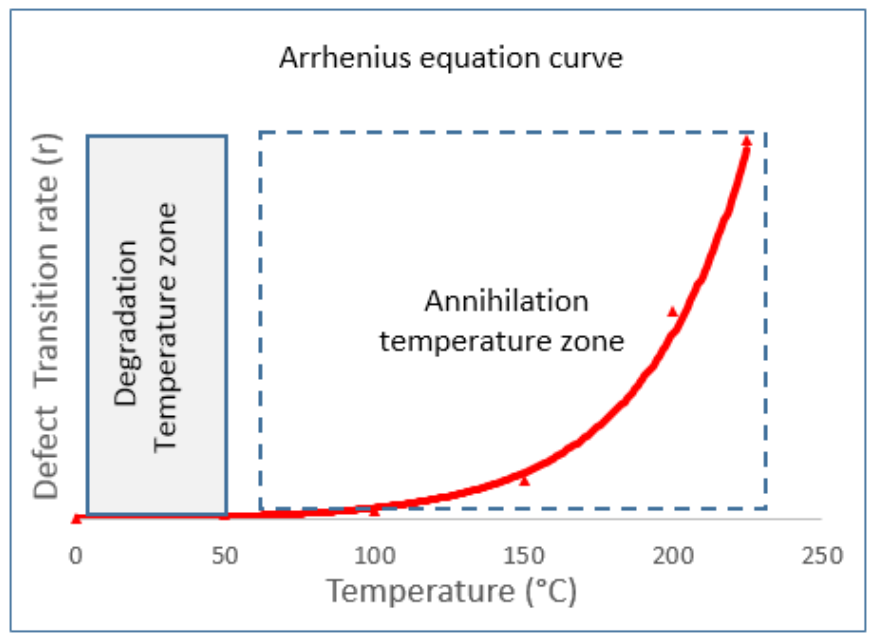

Figure 9. Arrhenius equation fitted-curve that shows the minimum temperature for defects to be transformed 
As Arrhenius plot in Figure 9 suggests, the $E_{A}$ at temperatures below $\sim 40^{\circ} \mathrm{C}$ is around $0.475 \pm 0.03 \mathrm{eV}$ [11] which is expected to be sufficient to activate the $\mathrm{B}-\mathrm{O}$ defect formation under light soaking. On the other hand, the temperatures above $\sim 80^{\circ} \mathrm{C}$ yielding $\sim 1.32 \pm 0.08 \mathrm{eV}$ is required to meet activation energy for passivation of $\mathrm{B}-\mathrm{O}$ defects (regeneration process). Also, high temperature is known to enhance the excitation of the defects (B-O defects in this case) from ground state to excited state, which makes them easier to be passivated.

\section{Hydrogenation (Defect Passivation)}

Passivation of the $B-O$ defects relies on the $H$ that resides in $\operatorname{SiN}_{x}$ ARC layer, which diffuses into Si bulk during contact co-firing. Although the effective passivation does not depend on the total amount of $H$ content in the $\mathrm{SiNx}$ ARC but on the amount, that are retained in the bulk Si. After contact co-firing step before the regeneration process, the $H$ in Si bulk can exist in four different states namely: (i) $\mathrm{Si}-\mathrm{H}$; bonded to dangling bonds and/or to a defect site, (ii) $\mathrm{B}-\mathrm{H}$ pairs (iii) molecular hydrogen as $\mathrm{H}_{2}$ that is likely in the absence of defect sites and (iv) interstitial atomic $H$ that occupies M-sites or bond-center (BC) as shown in Figure 10. [14]. Of these states, atomic $H$ has the lowest dissociation energy of $\sim 0.3 \mathrm{eV}$ [12], and $\sim 3.55 \mathrm{eV}, \sim 1.8 \mathrm{eV}$ for $S i-H$ and $B-H$, respectively. If sufficient energy is provided to Si bulk, the $H$ dissociates from its bonds and resides in $\mathrm{BC}$ position that can be mobilized even at room temperature. Thus, for the $H$ to passivate the $B$ - $O$ defects during regeneration process, it should be already mobilized or at least the bond can be broken readily with small amount of energy.

As noted in Figure 4, for the degradation step when the cell is exposed to 0.1 sun at $40^{\circ} \mathrm{C}$, the activation energy is only $\sim 0.5 \mathrm{eV}$. Under this condition, the generation rate of $B-O$ complex surpasses the passivation with available $H$ in the $S i$ bulk so that the minority carrier lifetime decreases and stabilizes at low value. However, when the cells are exposed to 1-sun at $80^{\circ} \mathrm{C}$ in the regeneration step, which corresponds to $\sim 1.3 \mathrm{eV}$ energy, the $H$ in $B$ - $H$ pairs are released to passivate the defects as well. This leads to the lifetime improvement as seen in the recovery before the stabilization where the defects are completely saturated with $H$. It is shown [13] that detaching the $H$ from $B-H$ pairs is improved by carrier injection level changing its charge state from $H^{+}$to $H^{0}$ whereby the dissociation energy of $\sim 1.79 \pm 0.04 \mathrm{eV}$ in the dark decreases to $\sim 1.14 \pm 0.07 \mathrm{eV}$ under illumination. Therefore, the regeneration conditions are capable of both mobilizing atomic $H$ and detaching the $H$ in $B-H$ pair.

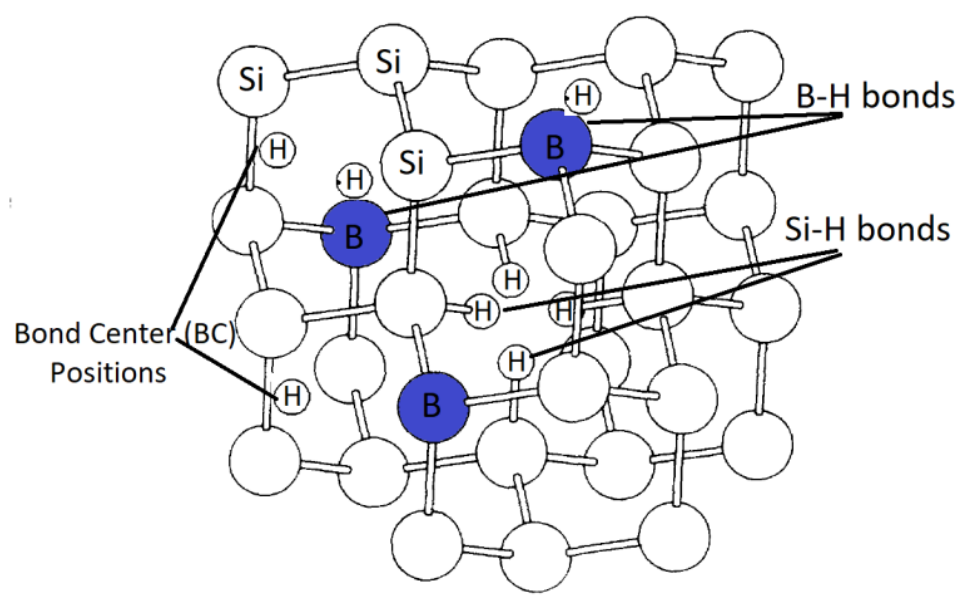

Figure 10. Illustrations of $\mathrm{H}$ bonds in the crystalline Si bulk structure

\section{Injection Level}

During regeneration, as the samples are illuminated at $\sim 1$-sun, the minority carrier injection level $(\Delta \mathrm{n})$ increases. According to the non-equilibrium mass action law given in Eq. 2 and one-diode model in Eq. 3, $\Delta \mathrm{n}$ is mostly controlled by bulk lifetime $\left(\tau_{b}\right)$ and surface recombination velocity $(S R V)$.

$$
n \cdot p=\left(n_{0} \cdot \Delta n\right) \cdot\left(p_{0} \cdot \Delta p\right)=n_{i}^{2} \cdot \exp \left({ }^{q V} / k T\right)
$$




$$
V_{O C}=\frac{k T}{q} \cdot \ln \left(\frac{J_{S C}}{J_{0}}+1\right)
$$

where $n$ and $p$ are the non-equilibrium electron and hole densities, $n_{0}$ and $p_{0}$ are equilibrium densities, $n_{i}$ is the intrinsic density, $k T$ is thermal energy, $q$ is the charge of electron, $\mathrm{J}_{\mathrm{SC}}$ is short circuit current density, $\mathrm{J}_{0}$ is saturation current density and $V$ is voltage.

In principle, higher minority carrier injection level increases the mobility of $H$ in the Si bulk, which is responsible for the defect passivation and hence the minority carrier lifetime recovery. In addition, higher injection level helps to excite the B-O defects from ground state to excited states, which increases the possibility of passivation. Since $\mathrm{V}_{\mathrm{OC}}$ is a measure of $\Delta \mathrm{n}$, it can be noted that regeneration rate is higher in the structures such as PERC solar cells that have high $\mathrm{V}_{\mathrm{OC}}$.

\section{CONCLUSION}

LID can be supressed in PERC structured silicon solar cell through regeneration, which requires the exposure of the cells to $\sim 1$ sun illumination at $\sim 80^{\circ} \mathrm{C}$ for extended period of time. Under this illumination level, the cells first degrade as the rate of $\mathrm{B}-\mathrm{O}$ complexes generation rate surpases the $H$ generation and passivation rates. However, as more $H$ released from B-H bonds are made available, passivation rate increases and hence the minority carrier lifetime increases and finally stabilizes. Thus, whether the cells are illuminated with $\sim 0.1$ sun at $40^{\circ} \mathrm{C}$ to degrade first, and then exposed to $\sim 1$ sun at $80^{\circ} \mathrm{C}$, or subjected to $\sim 1$ sun at $80^{\circ} \mathrm{C}$ directly, the same level of stabilization can be attained. The stabilization of the minority carrier lifetime in the solar cells thus require hydrogen to passivate the B-O complexes. It can therefore be understood that regeneration encompasses degradation, recovery and subsequent stabilization. And critical to regeneration are temperature and time, hydrogenation, and carrier injection levels.

\section{REFERENCES}

[1] Crabb RL. Photon induced degradation of electron and proton irradiated silicon solar cells. IEEE Transactions on Nuclear Science. 1973 Dec;20(6):243-9. https:// doi.org/10.1109/TNS.1973.4327402

[2] Schmidt J, Bothe K. Structure and transformation of the metastable boron-and oxygen-related defect center in crystalline silicon. Physical review B. 2004 Jan 22;69(2):024107. https://doi.org/10.1103/PhysRevB.69.024107

[3] Glunz SW, Rein S, Warta W, Knobloch J, Wettling W. Degradation of carrier lifetime in Cz silicon solar cells. Solar energy materials and solar cells. 2001 Jan 1;65(1-4):219-29. https://doi.org/10.1016/S09270248(00)00098-2

[4] Unsur V, Hussain B and Ebong A. Complete Recovery of Light Induced Degradation of Cz Silicon Solar Cells with Rapid Thermal Processing. IEEE 43rd Photovoltaic Specialists Conference (PVSC).2016, https://doi.org/10.1109/PVSC.2016.7749695.

[5] Ebong A, Chen N, Chowdhury A and Unsur V. The impact of rapid thermal processing (RTP) on crystalline silicon solar cell performance and light induced degradation (LID). IEEE 42nd Photovoltaic Specialists Conference (PVSC), Jun. 2015. https://doi.org/ 10.1109/PVSC.2015.7355879.

[6] Sopori B, Basnyat P, Devayajanam S, Shet S, Mehta V, Binns J, Appel J. Understanding light-induced degradation of c-Si solar cells. In2012 38th IEEE Photovoltaic Specialists Conference 2012 Jun 3 (pp. 001115001120). IEEE. https://doi.org/10.1109/PVSC.2012.6317798

[7] Herguth A, Schubert G, Kaes M, Hahn G. A new approach to prevent the negative impact of the metastable defect in boron doped cz silicon solar cells. Photovoltaic Energy Conversion, Conference Record of the 2006 IEEE 4th World Conference on, IEEE, 2006, pp. 940-943. https://doi.org/10.1109/WCPEC.2006.279611

[8] Münzer KA. Hydrogenated silicon nitride for regeneration of light induced degradation. In Proceedings of the 24th European Photovoltaic Solar Energy Conference 2009 Sep 21 (pp. 1558-1561).

[9] Wilking S, Beckh C Ebert S, Herguth A, Hahn G. Influence of bound hydrogen states on BO-regeneration kinetics and consequences for high speed regeneration processes. Solar Energy Materials and Solar Cells 131, pp. 2-8, 2014. https://doi.org/10.1016/j.solmat.2014.06.027 
[10] Herguth A, Horbelt R, Wilking S, Job R, Hahn G. "Comparison of BO Regeneration dynamics in PERC and AlBSF solar cells, 5th International Conference on Silicon Photovoltaics, SiliconPV 2015 https://doi.org/10.1016/j.egypro.2015.07.012

[11]Bothe K and Schmidt J. "Electronically activated boron-oxygen-related recombination centers in crystalline silicon", Journal of Applied Physics, vol. 99. https://doi.org/ 10.1063/1.2140584

[12] Corbett JW, Sahu SN, Shi TS. Atomic and Molecular Hydrogen in the Si Lattice. Physics Letters A, vol. 93A303, 1983. https:// doi.org/10.1016/0375-9601(83)90794-6

[13]Zundel T, Weber J. Boron reactivation kinetics in hydrogenated silicon after annealing in the dark or under illumination, Phys. Rev. B 43 (5) (1991) 4361. https://doi.org/10.1103/PhysRevB.43.4361

[14] Van de Walle CG and Street RA, "Structure, energetics, and dissociation of Si-H bonds at Dangling Bonds in Silicon", Physical Review B vol. 49, no 20, 1994. https:// doi.org/10.1103/PhysRevB.49.14766

[15] Vargas C, Nie S, Chen D, Chen C, Hallam B, Coletti G, Hameiri Z. Degradation and Recovery of n-type MultiCrystalline Silicon Under Illuminated and Dark Annealing Conditions at Moderate Temperatures, IEEE Journal of Photovoltaics vol. 9 no. 2, pp. 355-363, 2018. https://doi.org/10.1109/JPHOTOV.2018.2885711

[16] Walter DC, Helmich L, Pernau T, Romer O, Schmidt J, Comparing Cz-Si PERC solar cells from various manufacturers regarding BO-related light-induced degradation and regeneration, Proceedings 36th European Photovoltaic Solar Energy Conference, p. 464, 2019

[17] Winter M, Walter DC, Bredemeier D, Schmidt J, Light-induced lifetime degradation effects at elevated temperature in Czochralski-grown silicon beyond boron-oxygen-related degradation, Solar Energy Materials and Solar Cells vol. 201 pp. 110060, 2019. https://doi.org/10.1016/j.solmat.2019.110060 